\title{
Safe Learning Environment Perception Scale (SLEPS): A Validity and Reliability Study
}

\author{
Sayed Masood Haidari (ii) 1,*, Fazilet Karakuş (ib) 1
}

${ }^{1}$ Mersin University, Faculty of Education, Department of Curriculum and Instruction, Mersin, Turkey

\section{ARTICLE HISTORY}

Received: 07 April 2019

Revised: 24 July 2019

Accepted: 18 August 2019

\section{KEYWORDS}

Psychological safety,

Emotional safety,

Classroom environment,

Relationships,

Validity ,

Reliability

\begin{abstract}
The purpose of this study was to develop and cross-validate a measurement scale on students' perception of a psychologically safe learning environment in the Turkish context. Primarily, the scale items underwent two rounds of expert review. Then, a series of item elimination or revisions were performed to improve their relevance to the content domain and their comprehensibility for the target group according to the CVI and modified kappa statistics. The results yielded a strong content validity and clarity of the items. Then, the exploratory factor analysis and parallel analysis were performed based on the data from 556 secondary school students (grade 5-8), which suggested a three-factor solution. The KMO was $0.942>0.50$ with significant Bartlett test values, $x^{2}(496)=$ $8295.592, p<0.001$ and the explained total variance was $50.622 \%$. Each item had a factor loading of $>0.58$ with $>0.40$ common correlations. To validate this structure, confirmatory factor analysis was conducted based on the data from a different group of students $(N=339)$. The goodness of fit indices, factor loadings, and the $t$ statistics supported a good-fitting measurement model, $x^{2}(N=339)=925.29, d f=461, p<0.001 ; x^{2} / d f=2$, $\mathrm{NFI}=0.94, \mathrm{NNFI}=0.97, \mathrm{CFI}=0.97, \mathrm{SRMR}=0.069, \mathrm{RMSEA}=0.055$. The convergent and discriminant validity were also supported. In general, the SLEPS has potential applicability both at the lower and upper secondary schools (public and private) and at the educational centers for the gifted.
\end{abstract}

\section{INTRODUCTION}

Nurturing a sense of emotional and psychological safety is essential in every learning environment to facilitate effective teaching and learning opportunities (Holley \& Steiner, 2005). Establishment of healthy relationships and positive social interactions in the classroom can be the main prerequisites to start forging an atmosphere of such kind. One thing is for sure that the adolescents today are sensitive to the negative and extreme behaviors, which can easily result in distraction, sense of fear and unlearning thereafter. They "need more emotional and social guidance to cope with social pressure and personal identity" (Beamon, 2001, p. 3). Thus, the classroom must better be ready to ease such pressures as the right place, where individuals are meant to be educated as worthy members of society. In other words, they need guidance and

CONTACT: Sayed Masood Haidari $\square$ haidarimasood@gmail.com $\equiv$ Mersin University, Faculty of Education, Department of Curriculum and Instruction, Çiftlikköy Campus, 33110 Mersin, Turkey 
support in promoting their self-confidence, self-esteem and emotional security to be raised as healthy members of the society from a social and psychological perspective. This will be, of course, possible when the classroom population is protected "from psychological or emotional harms" (Holley \& Steiner, 2005, p.50). Creating a safe space in the classroom, where student identity and individuality are valued and nourished is essential in enforcing student connectedness to the learning environment. This is what Foldy, Rivard, and Buckley (2009) refer to as identity safety. Identity safety means upholding a perception that nobody will despise my social position within a group of learners. Though Foldy et al. (2009) relate the identity safety to a learning environment where individuals come from different racial backgrounds; its vitality is sensed in every academic context that accommodates learners with different backgrounds in terms of their individual needs, unique abilities, personal characteristics and so forth.

The word safe space here is a metaphoric attribution to a learning environment, where problematic issues, hard feelings, behavioral problems, and unnecessary pressures are impeded (Gayle, Cortez \& Preiss, 2013; Holley \& Steiner, 2005). Instead, a sense of connectedness to the classroom and willingness to engage in the activities are nourished in students, getting them convinced that the classroom is a psychologically safe place for learning, "where risks can be taken, mistakes can be made, and understanding can be gained" (Gayle et al., 2013, p. 2). Herewith, students should feel free to share their honest opinions, ask questions and learn enthusiastically without being subjected to embarrassment or humiliation (Turner \& Braine, 2015). If they do not feel mentally safe and comfortable, critical thinking will not flourish and the ideas shared will not be real, but fabricated. Raghallaigh and Cunniffe (2013) argue that experiencing uncertainties and sense of fear hinder student involvement in classroom activities. Feeling psychologically unsafe can be among the main reasons that increase uncertainties in students. As a result, they might be concerned about the consequences of giving wrong answers or bringing up questions with a fear that might reflect their ignorance. Beamon (1993) contemplates that establishing a safe learning space in the classroom to improve student thinking ability is interrelated with how "teacher interacts with, responds to and challenges" them by asking well-formulated cognitive questions and facilitating their participation in discussions (p. 91).

Given that self-disclosure, risk-taking, critical thinking, and positive relationships are fostered if individuals feel safe amongst a group of learners within the classroom, then setting up a psychologically safe learning atmosphere is mandatory. To build a safe and welcoming learning environment, everyone in the classroom is supposed to feel secure (Foldy et al., 2009). Besides, students should not get punished or ridiculed for their ways of thinking. Instead, they must be encouraged "to take risks, honestly express their opinions... share and explore their knowledge, attitudes, and behaviors" and make the classroom a safe haven for them to progress in individual level (Holley \& Steiner, 2005, p. 50). However, bullying, harassment, and ridicule may seriously hurt students' feelings and negatively affect their learning process, curbing their participation in classroom activities. A safe and desirable learning environment requires creating participative and rich learning opportunities to the students so that they feel connected to their teacher and classmates. Vice versa, having a sense of belonging or connectedness to the classroom improves student participation and participation can promote a feeling of safety and acceptance (Frisby, Berger, Burchett, Herovic \& Strawser, 2014). This will, in turn, improve student-student and student-teacher relationships in addition to building a trusted plus respectful learning atmosphere in the classroom. Establishing positive and trusted relationships in the classroom can give the type of morale they need and encourage them to reveal their thoughts instead of protecting their image and individual self from potential embarrassments. 
A study with gifted-students and students having emotional or behavioral disorders in an Australian secondary school revealed that teacher behaviors contribute to building positive relationships between the teacher and students, resulting in productive learning opportunities thereafter (Capern \& Hammond, 2014). The study further reported that the gifted students valued the friendliness and cordiality of the teachers that ultimately leads to productive learning. However, the students with emotional or behavioral disorders considered the teachers' behavioral characteristics "that displayed warmth, understanding and patience" as preconditions to effective learning (Capern \& Hammond, p. 46). Treating students with respect, giving equal opportunities for self-disclosure, allowing peer assistance, and not discriminating between them were among the other findings that indicate the importance of approachability of the teacher displayed through his/her behaviors, influencing student learning.

Truly, active student engagement in learning results in improved learning, better academic performance, and personal-growth (Raghallaigh \& Cunniffe, 2013; Frisby et al., 2014). Participation, of course, could be reinforced by cultivating a sense of confidence in students and fostering challenging, yet enjoyable learning experiences (Gayle et al., 2013). Thus, encouraging in-class student interactions and building sincere relationships falls to the teachers to control the situation in favor of the students. In the meantime, the approachability of the teacher, his willingness to listen to the student voices, cherishing diverse opinions and attending student needs in individual level are vital in creating a desirable learning space that is psychologically safe (Gillen, Wright, \& Spink, 2011).

Nevertheless, safe learning spaces must not be confused with unchallenging and conflict-free environments (Boostrom, 1998; Holley \& Steiner, 2005). Where there is no conflict, there is no learning and critical thinking. Here, conflict refers to the diversity of thoughts, conflict of ideas and disagreements as natural parts of learning. The presence of psychological safety "may decrease barriers to engagement and allow individuals...to interact with the world around them" (Wanless, 2016, p. 6). This may persuade students to come out of their comfort zones in order to reveal their individuality by expressing themselves openly and honestly as well as develop their knowledge and skills. If students do not get exposed to academic challenges, they may not progress as required. Boostrom (1998) maintains that "...teachers need to manage conflict, not prohibit it" to flourish "critical thinking" in students (p. 407). To tackle academic challenges and conflictive ideas, mental safety needs to be insured and students should get encouraged to voice their opinions bravely in an academic context (Boostrom, 1998). However, accepting every standpoint without constructive criticisms might hinder personal-growth. Simply put, students must feel emotionally safe in order to be open to critical evaluation of their opinions by other students in the class.

Surely, not being mocked and disgraced because of uncommon ideas, incorrect answers or asking questions differ from alerting students of their ignorance and learning deficiencies (Holley \& Steiner, 2005). According to Wanless (2016), discomforts are inevitable when new opinions are shared, but they do not have to get in the way of the students to achieve their goals. Hereby, two main responsibilities fall to the teacher while trying to create a psychologically safe atmosphere: i.e. a) inhibiting annoying acts and bad behaviors in the class that might prevent taking creative risks, and b) informing students of their academic progress without being judgmental and discriminative. If students are judged for what and who they are, it may undermine their learning and push them towards alienation.

However, how the psychologically safe learning climate is perceived might differ from student to student, (i.e. gifted-students from normal students and students with different socioeconomic backgrounds) particularly in lower secondary education level. As noted before, middle school students or so-called adolescents (Beamon, 1993) are more susceptible to the negative features of psychologically unsafe learning environments. Beamon (1993) 
conceptualizes that at the secondary "grade level, where students' intellectual capacity is rapidly unfolding", promoting their "thinking ability is a critical one" (p. 92). As it appears, few empirical studies exist (mostly qualitative ones) as regards psychologically safe learning environments. The sample in the existing studies is mostly from universities or colleges. Besides, a valid and reliable quantitative data collection tool was not found about the student perception in this regard. Therefore, this study was conducted to develop a safe learning environment perception scale (SLEPS) suitable to the secondary level students (grade 5-8) from diverse socioeconomic backgrounds studying at public, private and gifted schools.

\section{METHOD}

\subsection{Participants}

The data were collected from a total of 651 secondary level students (grade 5-8) for the exploratory factor analysis (EFA). However, this number dropped to 556 after the removal of eight incomplete and 87 multivariate outliers. The sample was selected from different socioeconomic backgrounds studying in the private or public schools and educational centers for the gifted students (i.e. extra schooling that the gifted-students receive in Science and Art Centers besides attending public schools) in Turkey (see Table 1). Their mean age was $M=$ 11.67 ( $S D=1.28$ ) of both gender. Secondly, another set of data was collected from 349 students for the confirmatory factor analysis (CFA), but this number decreased to 339 after ten univariate or multivariate outliers were removed. The mean age of the students in this group was $M=$ $11.86(S D=1.31)$.

Table 1. Demographic information about the sample in EFA $(N=556)$ and CFA $(N=339)$

\begin{tabular}{llllll}
\hline \multirow{2}{*}{ Variables } & \multirow{2}{*}{ Category } & EFA & \multicolumn{3}{c}{ CFA } \\
\cline { 3 - 6 } School & & $n$ & $\%$ & $n$ & $\%$ \\
& Public & 301 & 54.1 & 142 & 41.9 \\
& Private & 203 & 36.5 & 102 & 30.1 \\
& Gifted & 52 & 9.4 & 95 & 28 \\
\hline Gender & Male & 292 & 52.5 & 162 & 47.8 \\
& Female & 264 & 47.5 & 177 & 52.2 \\
\hline Grade Level & Five & 191 & 34.4 & 121 & 35.7 \\
& Six & 153 & 27.5 & 66 & 19.5 \\
& Seven & 100 & 18 & 82 & 24.2 \\
& Eight & 112 & 20.1 & 70 & 20.6 \\
& Total & 556 & 100 & 339 & 100 \\
\hline
\end{tabular}

\subsection{Item Development, Expert Review and Content Validity Index}

The items were developed after reviewing relevant literature on safe learning environment. Initially, 90 items were generated. However, this number dropped to 85 after removing five items because of their similarity to the other items. All of them were written in the Turkish language because of the sample characteristics. To ensure the content validity of the items, an expert review form was devised with two criteria of relevancy and clarity being measured by a four-point scoring system. This form required the experts in the education field to rate the relevance of the items to the content domain and the level of their clarity or comprehensibility as " $1=$ not relevant, $2=$ somewhat relevant, $3=$ quite relevant, $4=$ highly relevant" (Pilot, Beck \& Owen, 2007, p.460). The same scoring system was applied to the clarity criteria from 1-4, 1 being not clear and 4 being highly clear. Afterward, two different expert reviews were conducted. At stage one, seven university Ph.D. lecturers with different expertise in the field of education were selected. Two of them were assessment and evaluation experts to evaluate the 
psychometric properties of the items. After they returned the review forms, the scores were entered in two different Excel tables to calculate the content validity index (CVI) and modified kappa.

CVI shows the "Degree to which an instrument has an appropriate sample of items for construct being measured" (Pilot \& Beck, 2006, p. 493) while "modified kappa statistics adjust for chance agreement" to the items agreed to be relevant by the experts; not their agreement on irrelevant ones (Pilot et al., 2007, p. 465). Moreover, items having an item level CVI (I-CVI) or kappa values of 0.80 or more were kept while others below that threshold were removed, though according to Pilot et al. (2007) an I-CVI of 0.78 is acceptable showing adequate content validity with three or more reviewers. However, according to Lynn (1986), the I-CVI should be ' 1 ' with three to five reviewers while it can be relaxed when they are more than five. This means that all the reviewers must agree on the relevance or the clarity of the items if they are five or under that number. With the removal of items under I-CVI of 0.80 , the number of items dropped to 68. After the recommended revisions, the second round of expert review was conducted with three reviewers, following the same procedure. Since the number of reviewers was three, then the I-CVI of ' 1 ' was considered acceptable (Lynn, 1986).

I-CVI was calculated by counting the number of reviewers who rated each item as 3 or 4 to the total number of reviewers. Then the scale level CVI (S-CVI) was calculated in two different ways to check the overall relevancy/clarity levels: a) calculating I-CVI average (S-CVI/AV) and, b) universal agreement of S-CVI (S-CVI/UA). S-CVI/AV was calculated by dividing the total of I-CVI to the total number of the items. However, the S-CVI/UA was computed by dividing the sum of items that received 3 or 4 from all reviewers to the sum of all items. SCVI/AV and S-CVI/UA of 0.80 or more were considered acceptable (Pilot \& Beck, 2006; Pilot et al., 2007). Further, the probability of chance agreement as the prerequisite of the modified kappa (also called $\left.k^{*}\right)$ was computed using this formula: " $\mathrm{P}_{\mathrm{c}}=[\mathrm{N} ! / \mathrm{A} !(\mathrm{N}-\mathrm{A}) \text { ! }]^{*} .5^{\mathrm{N}}$ " $(\mathrm{Pc}=$ probability of chance agreement, $\mathrm{N}=$ number of experts, $\mathrm{A}=$ number of experts giving a score of 3 or 4 to an item). After that, $k^{*}$ was calculated by employing the I-CVI proportion of agreement and Pc through "K = (I-CVI - Pc) / (1 - Pc)" formula (Zamanzadeh et al., 2015, p. 69; Pilot et al., 2007, p. 466).

Followed by two rounds of expert review, major item revisions, application of different interrater tests, and elimination of irrelevant items, the last version of the SLEPS was devised containing a total of 59 items in a five-point Likert scale format to be responded accordingly by the selected sample ( $5=$ Strongly disagree, $4=$ Agree, $3=$ Undecided, 2, Disagree, $1=$ Strongly Disagree). Demographic information about the participants of the study was sought as regards their school type, grade levels, gender, and age.

\subsection{Analysis}

After the data were collected, they were screened to identify the incomplete cases. As such eight cases were found and discarded. The remaining data were entered into the SPSS program and the negative items were reverse coded. Then the dataset was screened for univariate and multivariate outliers. For detecting the univariate outliers, the standardized $z$ scores were evaluated and for multivariate outliers, the Mahalanobis Distant values were compared to Chisquare Table of the critical values as presented in Tabachnick and Fidell (2013). To ensure the factorability of the data set, the Kaiser-Meyer-Olkin (KMO) and Bartlett Test of Sphericity were run. The KMO value was expected to be over 0.6 and the Bartlett test results to be significant at $p<.001$ level (Aldrich \& Cunningham, 2016). The linearity check between the variables, and the "Multicollinearity and singularity" analysis were also conducted as the prerequisites to the exploratory factor analysis (EFA) outlined in Tabachnick and Fidell (p. 674). 
After conducting the required tests above, a principal components analysis (PCA) was run followed by a principal axis factoring (PAF) to extract the latent variables for the SLEPS. These analyses were employed "to describe and summarize data by grouping together variables that are correlated" under the extracted latent variables (Tabachnick \& Fidell, 2013, p. 614). The size of loading for each variable was decided to be at least 0.45 to be retained. Besides, the eigenvalue greater than ' 1 ' was considered acceptable for factor determination. To ensure that the factor determination through eigenvalues and scree plot is not by chance, the Horn's parallel analysis (PA) was run as an alternative objective method in factor determination (Patil, Singh, Mishra, \& Donavan, 2008). Sometimes, relying on eigenvalues greater than ' 1 ' rule and scree plots can be misleading and lead to over-estimation of factors due to its subjectivity. According to Patil et al. (2008), PA provides information that is more accurate in this regard. It is conducted by comparing the actual eigenvalues of the extracted factors "with eigenvalues extracted from a randomly generated correlation matrix having the same sample size and number of variables", where the eigenvalue in the actual data is expected to be larger than the values estimated in the simulated data for a factor to be retained (Patil et al., 2008, p. 164; Williams et al., 2010; Çokluk \& Koçak, 2016). To calculate PA, a "Web-based PA engine", developed by Patil et al. (2007), was used where only the total number of items and the sample size is required to generate the random eigenvalues (Patil et al., 2008, p, 168; see Patil et al., 2007). In addition, to decide on rotation type, the correlations between the factors were evaluated. According to Aldrich and Cunningham (2016), if factors are correlated an oblique rotation technique is used. Otherwise, an orthogonal rotation is preferred. Analyses were repeated after excluding two types of items: a) complex items cross loading on more than one factor with less than 0.10 difference and $b$ ) the items below the specified cutoff value for the factor loading (Seçer, 2013).

Furthermore, a CFA was performed, through Maximum Likelihood estimation method in LISREL 8.71, to validate the measurement model for the SLEPS. A series of assumption tests were conducted as done in EFA. The missing values lower than $5 \%$ were imputed via mean substitution. Then the chi-square value $\left(x^{2}\right)$ and the goodness of fit statistics were analyzed and reported by evaluating the resultant values of Root Mean Square Error of Approximation (RMSEA), Normed Fit Index (NFI), Non-Normed Fit Index (NNFI), Comparative Fit Index (CFI), and Standardized Root Mean Square Residual (SRMR). The RMSEA and SRMR values of 0.08 or lower plus the NFI, NNFI, and CFI values of 0.90 or over were considered as adequate model fit indexes (Stevens, 2009; Seçer, 2013, p. 152; Pituch \& Stevens, 2016, p. 654). Besides, the normed chi-square was calculated by dividing the $x^{2}$ to its degree of freedom, considering the recommended ratio of 3 or smaller (Walts, Strickland, \& Lenz, 2010). Next, the Chronbach's alpha, the average variance extracted (AVE), the composite reliability (CR), and the squared correlation between the factors were calculated to provide results for the internal consistency, convergent, and discriminant validity respectively.

\section{FINDINGS}

\subsection{Content Validity Computation Results}

The first round of expert review on item relevancy and clarity resulted in major revisions in accordance with the recommendations made. Besides, 17 out of 85 items were eliminated because of receiving low relevancy scores (I-CVI $\left.<0.80, k^{*}<0.80\right)$. The $\mathrm{S}-\mathrm{CVI} / \mathrm{AV}$ test results indicated a high level of overall relevancy of the items (0.916) to the content domain, while $S$ CVI/UA (0.682) indicated the opposite. In addition, the clarity test results showed that most of the items needed revision, for they were not comprehensible enough. As the item level analyses indicated (I-CVI < $0.80, k^{*}<0.80$ ), 34 out of 85 items were rated either ' 1 ' or ' 2 ' needing major revisions to make them conceptually comprehensible to the lower secondary level students. Although S-CVI/AV was found to be at an adequate level (0.818), the S-CVI/UA score was 
unacceptable (i.e. 0.60). Therefore, after fundamental changes were made to increase the clarity of the items, a second expert review form was devised with 68 items. This time three experts rated the relevancy and clarity of the items once more. Only one item was eliminated because of a low I-CVI (0.66).

However, the results of S-CVI/AV and S-CVI/UA show that the overall relevancy level of the scale items is excellent ( 0.995 and 0.985 respectively). Similarly, the clarity scores of the items considerably increased considering the S-CVI/AV and S-CVI/UA (0.961 and 0.882 respectively) above the acceptable level although one of the experts rated eight items as ' 2 ' meaning not clear enough and thereby suggested some corrections. She also suggested eliminating some of the items because of their similarity to other items. Therefore, the final form of SLEPS was devised with the inclusion of 59 and exclusion of nine items, as they were too similar to some other items in the form in terms of meaning.

\subsection{Exploratory Factor Analysis}

To extract the potential latent variables for the SLEPS, a PCA followed by a PAF was employed to see how the results compare. However, as a conservative approach in factor extraction, PCA results were prioritized. Prior to these analyses, the required assumption tests were run. As mentioned elsewhere, the dataset was scrutinized for possible univariate and multivariate outliers. The analysis of the standardized $z$ scores indicated that no univariate outliers exist. However, the comparison between the Mahalanobis distance values of multiple regression and the Chi-square table of critical values considering the degree of freedom of 59 at $p<.001$ level indicated that 87 cases have a Chi-square of $x^{2}=90.607$ or more, fall into multivariate outliers category and therefore were excluded from the study (Tabachnick \& Fidell, 2013, p. 952). This way, the sample size dropped to 556 for the subsequent analysis. Sample sizes of 100, 300, and 1000 are classified as poor, good and excellent respectively (Field, 2009). To ensure the factorability of the data, the KMO sampling adequacy and Bartlett Test of Sphericity were run. The KMO, $0.942>0.50$, and the Bartlett test results, $x^{2}(496)=8295.592, p<0.001$, supported the suitability of the data for factorization (Williams, Onsman, \& Brown, 2010).

Moreover, the data indicated normal distribution according to standardized $\mathrm{z}$ scores and the similarity of the central tendency measures (mean, median and mode) across all variables. Besides, because of the impracticability of analyzing pair-wise linearity scatter plots of all the variables in the study, it was decided to check the linearity between the variables holding the most negative and the most positive skewness values. The result showed a nonlinear relationship between the two. Hence, the data were screened for multicollinearity, singularity and auto-correlation problems. According to the evaluation of the coefficients table, the variance inflation factors (VIF) were $<5$, the Tolerance values $>0.20$ in all cases, and the Durbin-Watson test value was 2 . These results prove that the respective problems mentioned do not exist in the data.

Finally, the initial PCA was run after the essential analysis made above. The factor loading for each item was decided to be at least 0.45 to be retained and the eigenvalues were set on ' 1 ' as a default acceptable level for factor determination (Tabachnick \& Fidell, 2013). These values ranged from 1.001-16.668 suggesting a nine-factor solution with the largest total variances explained by $55.65 \%$. However, the sub-factor with $5 \%$ explained variances were preferred. When the initial total variances of the eigenvalues were evaluated, only the first three factors met this criterion explaining $42.35 \%$ of total variances. Contrarily, the initial PAF analysis of EFA yielded a relatively different result in terms of the explained total variances both for the nine-factor (47.41\%) and the three-factor solutions (39.71\%). In general, the eigenvalues with the explained variances of $5 \%$ or more, as well as the inflexion point on the scree plot, 
suggested a three-factor solution (see Figure 1). The factors were not determined only with these two measures but also by considering the PA results (see Table 2).

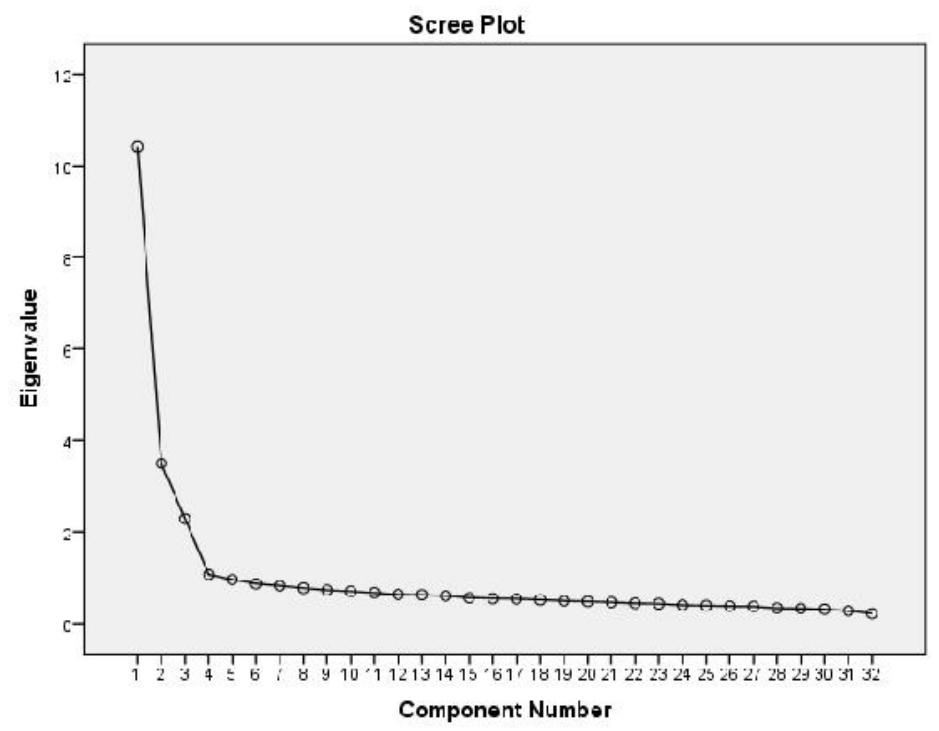

Figure 1. The Scree plot, showing the number of retainable factors

As shown in Table 2, the comparison between the real eigenvalues generated by SPSS and the randomly generated eigenvalues through a web-based parallel analysis (Patil et al., 2007), indicate that the retained factors through PCA is not by chance, because the first three factors hold greater eigenvalues in the real dataset than the random one. However, in the fourth factor the random eigenvalue (1.591141) was greater than that of the real one (1.064), confirming the three-factor solution suggested by SPSS.

Table 2. Eigen values and the explained variances after PCA and PAF

\begin{tabular}{lcccccc}
\hline & \multicolumn{2}{c}{ Eigenvalues } & \multicolumn{2}{c}{ PCA } & \multicolumn{2}{c}{ PAF } \\
\cline { 2 - 7 } Factors & Real & Random & \% of Variance & Cumulative \% & \% of Variance & Cumulative \% \\
\hline 1 & 10.420 & 1.753312 & 32.561 & 32.561 & 30.908 & 30.908 \\
2 & 3.496 & 1.686328 & 10.925 & 43.487 & 9.239 & 40.147 \\
3 & 2.283 & 1.637604 & 7.135 & 50.622 & 5.399 & 45.546 \\
\hline
\end{tabular}

The eigenvalues for the three factors ranged from 2.283 to 10.420 and the explained variances of the individual factors ranged from 7.135 to $32.561 \%$ with explained total variances of 50.622 $\%$. However, in comparison to PCA results, the PAF analysis yielded smaller explained variances, ranging from 5.399 to 30.905 , with a cumulative percent of explained total variances of $45.546 \%$ showing a difference of around $5 \%$.

Considering the eigenvalues and the scree plot, the number of factors was set on three. To decide on rotation type, the correlation between the factors was evaluated. After ensuring they are inter-correlated, an oblique rotation of Promax was preferred. In this regard, Brown (2015) argues, "oblique rotation provides a more realistic representation of" inter-correlation between the factors. However, if they are not correlated, "oblique rotation will produce a solution that is virtually the same as one produced by orthogonal rotation" (Brown, 2015, p. 28). Afterward, the communalities table was evaluated and the items being correlated under .40 were noted for later exclusion. When the rotated component matrix was evaluated several items were found either cross-loading on more than one factor or under cutoff value $(0.45)$ for factor loadings. With the exclusion of these under-correlated and complex items (27 out of 59), a 32-item scale was devised through PCA (See Table 3). 
Table 3. The analyses result for the 32-item scale after the PCA with Promax rotation

\begin{tabular}{|c|c|c|c|c|c|}
\hline \multirow{2}{*}{ Items } & \multicolumn{4}{|c|}{ Factor Loadings } & \multirow[b]{2}{*}{ Item-Total Correlations } \\
\hline & F1 & $\bar{F} 2$ & F3 & $\overline{h^{2}}$ & \\
\hline Item36 & .815 & & & .599 & $.605 * *$ \\
\hline Item45 & .783 & & & .599 & $.655^{* *}$ \\
\hline Item53 & .781 & & & .579 & $.647 * *$ \\
\hline Item6 & .771 & & & .557 & $.515^{* *}$ \\
\hline Item30 & .758 & & & .530 & $.560 * *$ \\
\hline Item29 & .755 & & & .556 & $.572 * *$ \\
\hline Item24 & .731 & & & .486 & $.615^{* *}$ \\
\hline Item34 & .693 & & & .523 & $.629 * *$ \\
\hline Item40 & .664 & & & .525 & $.636 * *$ \\
\hline Item58 & .658 & & & .551 & $.594 * *$ \\
\hline Item48 & .631 & & & .505 & $.675^{* *}$ \\
\hline Item 28 & .624 & & & .428 & $.585^{* *}$ \\
\hline Item59 & .623 & & & .466 & $.543 * *$ \\
\hline Item1 8 & .615 & & & .404 & $.562 * *$ \\
\hline Item47 & .596 & & & .405 & $.627 * *$ \\
\hline Item 21 & .561 & & & .428 & $.616 * *$ \\
\hline Item19 & & .799 & & .558 & $.542 * *$ \\
\hline Item51 & & .709 & & .595 & $.557 * *$ \\
\hline Item42 & & .708 & & .500 & $.631 * *$ \\
\hline Item8 & & .695 & & .475 & $.441 * *$ \\
\hline Item3 & & .665 & & .490 & $.558 * *$ \\
\hline Item33 & & .641 & & .410 & $.536 * *$ \\
\hline Item41 & & .639 & & .449 & $.593 * *$ \\
\hline Item31 & & .578 & & .458 & $.588 * *$ \\
\hline Item22 & & .571 & & .443 & $.593 * *$ \\
\hline Item55_R & & & .775 & .655 & $.505^{* *}$ \\
\hline Item39_R & & & .728 & .507 & $.347 * *$ \\
\hline Item50_R & & & .723 & .505 & $.349 * *$ \\
\hline Item44_R & & & .710 & .512 & $.320 * *$ \\
\hline Item57_R & & & .677 & .534 & $.447 * *$ \\
\hline Item32_R & & & .675 & .510 & $.424 * *$ \\
\hline Item46_R & & & .657 & .455 & $.427 * *$ \\
\hline $\begin{array}{l}\text { Explained Variances } \\
(50.622 \%)\end{array}$ & $32.561 \%$ & $10.925 \%$ & $7.135 \%$ & & \\
\hline
\end{tabular}

\begin{tabular}{llll}
\hline Cronbach's Alpha & .93 & .86 & .84
\end{tabular}

Note: F1 = Teacher Approachability, F2 = Positive Peer Relationships, F3 = Lack of Identity Safety, $* * p<0.01$

As reported elsewhere, the resultant item elimination process contributed to an increase in the explained total variance from $46.756 \%$ to $50.622 \%$. Similarly, the explained total variance obtained through PAF also increased from $39.71 \%$ to $45.546 \%$, which is relatively smaller than the one obtained through PCA (50.622\%).

As illustrated in Table 3, the first factor contains 16 items, the second 9 and the last 7 . Besides, the third factor contains only negative items that were reverse-coded and indicated with $\mathrm{R}$ letter at the end. The communalities column $\left(h^{2}\right)$ shows that the common correlation value for each 
item was above 0.40 and the item-total correlations were significant across all variables $(p<$ 0.01), ranging from minimum 0.320 to maximum 0.675. Similarly, the factor loadings were high enough, ranging from 0.561 to 0.815 for the first factor, 0.571 to 0.799 for the second, and 0.657 to 0.775 for the third factor. All the variances explained by each factor are given beneath Table 3 including the Cronbach's Alpha values of reliability. The Cronbach's alpha was .93 for the first factor, 0.86 for the second, and .84 for the third. These results indicate that this measurement scale (i.e. SLEPS) comprising of three factors and 32 items is reliable because of its high internal consistency across all observed variables and their respective latent variables. Then these latent variables were named according to the sub-dimensions of the safe learning environment in the literature. So to speak, the first factor was named as Teacher Approachability whereas the second and third were named as Positive Peer Relationships and Lack of Identity Safety respectively.

\subsection{Confirmatory Factor Analysis}

A correlated traits model of CFA, based on data from 339 secondary school Turkish students, was performed to cross-validate the three-factor SLEPS developed in the present study. Initially, the negative items were reverse-coded followed by a series of assumption tests. So doing, one univariate and nine multivariate outliers were identified and therefore excluded. Fifteen cases with less than $5 \%$ missing values were imputed through mean substitution. However, there was no issue of concern regarding the singularity and multicollinearity since the VIF $(<5)$ and Tolerance $(>0.20)$ values were under the threshold. The model fit indices, estimated through Maximum Likelihood approach, were compared to and interpreted according to the recommended cutoff values, within acceptable ranges, in the literature (Hu \& Bentler, 1999, p. 27; Stevens, 2009; Kline, 2016; Pituch \& Stevens, 2016, p. 654).

Table 4. The model fit measures for the SLEPS

\begin{tabular}{lcccc}
\hline Fit Indices & Perfect Fit & Adequate Fit & Fit Indices of SLEPS & Model Fit Level \\
\hline$x^{2} / d f$ & o or $<2$ & $\leq 3$ & 2 & Adequate \\
NFI & 0.95 or close to 1 & $\geq 0.90$ & 0.94 & Adequate \\
NNFI (TLI) & 0.95 or close to 1 & $\geq 0.90$ & 0.97 & Perfect \\
CFI & 0.95 or close to 1 & $\geq 0.95$ & 0.97 & Perfect \\
SRMR & 0 or $\leq 0.050$ & $\leq 0.08$ & 0.069 & Adequate \\
RMSEA & 0 or $\leq 0.050$ & $\leq 0.08$ & 0.055 & Adequate \\
\hline
\end{tabular}

From Table 4 it can be seen that fit indices for the measurement model under three factors support a good fit without any modification, $x^{2}(N=339)=925.29, d f=461, p<0.001 ; x^{2} / d f=$ $2, \mathrm{NFI}=0.94, \mathrm{NNFI}(\mathrm{TLI})=0.97, \mathrm{CFI}=0.97, \mathrm{SRMR}=0.069, \mathrm{RMSEA}=0.055$. Here, the normed $x^{2} / d f$, NFI, SRMR, and RMSEA were adequate. However, the NNFI (TLI) and the CFI were at the perfect level since these indexes were very close to 1 (Hu \& Bentler, 1999). Similarly, the second order CFA under one factor yielded the same results in terms of fit indices and parameter estimates. Therefore, no modification was performed since the suggested model was of a good fit. Moreover, Table 5 indicates that the standardized parameter estimates (i.e. factor loadings) range from 0.59 to 0.77 for Teacher Approachability, 0.50 to .71 for Positive Peer Relationships and 0.45 to 0.75 for Lack of Identity Safety, all with significant $t$ statistics $(p<0.01)$. The standardized and unstandardized factor loadings for the individual items, their error terms, and $t$ values can be evaluated in the respective table. 
Table 5. Standardized and unstandardized parameter estimates, standard errors, and $t$ values

\begin{tabular}{|c|c|c|c|c|c|}
\hline Factors & Items & Unstandardized Estimates & Standardized Estimates & $S E$ & $t$ \\
\hline Teacher & Item36 & 0.60 & 0.67 & 0.55 & $13.56^{* *}$ \\
\hline \multirow[t]{15}{*}{ Approachability } & Item45 & 0.73 & 0.64 & 0.59 & $12.85^{* *}$ \\
\hline & Item53 & 0.79 & 0.67 & 0.55 & $13.63 * *$ \\
\hline & Item6 & 0.64 & 0.70 & 0.50 & $14.50 * *$ \\
\hline & Item30 & 0.58 & 0.61 & 0.63 & $12.07 * *$ \\
\hline & Item29 & 0.48 & 0.63 & 0.61 & $12.47 * *$ \\
\hline & Item24 & 0.82 & 0.77 & 0.41 & $16.40 * *$ \\
\hline & Item34 & 0.71 & 0.68 & 0.53 & $13.92 * *$ \\
\hline & Item 40 & 0.68 & 0.67 & 0.55 & $13.65 * *$ \\
\hline & Item58 & 0.75 & 0.63 & 0.61 & $12.46^{* *}$ \\
\hline & Item 48 & 0.75 & 0.63 & 0.60 & $12.51 * *$ \\
\hline & Item 28 & 0.71 & 0.59 & 0.66 & $11.49 * *$ \\
\hline & Item59 & 0.89 & 0.68 & 0.53 & $13.95^{* *}$ \\
\hline & Item18 & 0.73 & 0.65 & 0.58 & $13.06 * *$ \\
\hline & Item47 & 0.69 & 0.61 & 0.63 & $11.95 * *$ \\
\hline & Item21 & 0.81 & 0.60 & 0.63 & $11.91 * *$ \\
\hline Positive Peer & Item19 & 1.03 & 0.71 & 0.50 & $14.12 * *$ \\
\hline \multirow[t]{8}{*}{ Relationships } & Item51 & 0.70 & 0.58 & 0.66 & $10.95 * *$ \\
\hline & Item 42 & 0.91 & 0.70 & 0.51 & $13.96 * *$ \\
\hline & Item8 & 0.59 & 0.61 & 0.63 & $11.62 * *$ \\
\hline & Item3 & 0.94 & 0.69 & 0.53 & $13.63 * *$ \\
\hline & Item33 & 0.75 & 0.50 & 0.75 & $9.21 * *$ \\
\hline & Item41 & 0.80 & 0.61 & 0.62 & $11.73 * *$ \\
\hline & Item31 & 0.77 & 0.61 & 0.63 & $11.72 * *$ \\
\hline & Item22 & 0.71 & 0.50 & 0.75 & $9.19 * *$ \\
\hline Lack of Identity & Item55_R & 1.13 & 0.75 & 0.43 & $14.82 * *$ \\
\hline \multirow[t]{6}{*}{ Safety } & Item39_R & 0.95 & 0.62 & 0.62 & $11.53 * *$ \\
\hline & Item50_R & 0.77 & 0.59 & 0.65 & $10.88^{* *}$ \\
\hline & Item44_R & 0.82 & 0.55 & 0.70 & $9.92 * *$ \\
\hline & Item57_R & 0.51 & 0.45 & 0.80 & $7.87 * *$ \\
\hline & Item32_R & 0.97 & 0.61 & 0.63 & $11.27 * *$ \\
\hline & Item46_R & 0.82 & 0.56 & 0.69 & $10.10 * *$ \\
\hline
\end{tabular}

Note: $* * p<0.01$

The reliability statistics of Cronbach's Alpha was calculated once again according to the final measurement model. As seen in Table 6, the alpha value was 0.919 for Teacher Approachability, 0.839 for Positive Peer Relationships, and 0.789 for Lack of Identity Safety. These results were similar to the reliability statistics calculated after EFA, showing an adequate level of internal consistency between the latent and observed variables.

In addition, the AVE values of the factors ranged from 0.36 to 0.43 , which are under the threshold of 0.50 (see Table 6). However, the CR values were found adequate (above 0.70), ranging from 0.791 to 0.922 . The latter findings indicate good reliability and therefore can be accepted as a piece of alternative evidence for convergent validity (Hair, Black, Babin, \& Anderson, 2014, p. 619; Kline, 2016, p. 313). 
Table 6. Cronbach's alpha, AVE, and CR

\begin{tabular}{lccc}
\hline Factors & $\alpha$ & AVE & CR \\
\hline 1. Teacher Approachability & 0.919 & 0.43 & 0.922 \\
2. Positive Peer Relationships & 0.839 & 0.38 & 0.845 \\
3. Lack of Identity Safety & 0.789 & 0.36 & 0.791 \\
\hline
\end{tabular}

Further, to ensure discriminant validity the AVE results were compared with that of squared correlation estimates between the constructs. Table 7 shows that squared correlations of the constructs are smaller than AVE supporting discriminant validity of the scale (Hair et al., 2014). However, the AVE statistics are below the 0.50 rule of thumb as noted earlier.

Table 7. The square of the between-factor correlation estimates compared to AVE

\begin{tabular}{lccc}
\hline Factors & 1 & 2 & 3 \\
\hline 1. Teacher Approachability & $(0.43)$ & & \\
2. Positive Peer Relationships & $0.31^{* *}$ & $(0.38)$ & \\
3. Lack of Identity Safety & $0.12^{* *}$ & $0.34^{* *}$ & $(0.36)$ \\
\hline
\end{tabular}

Note: AVE statistics are given in parentheses, ${ }^{* *} p<0.001$

Therefore, as another measure for discriminant validity, the goodness-of-fit indices of the scale was computed for the one-factor model and then the results were compared to that of the threefactor model. The comparison between these fit indexes, the one and three construct models, indicated substantially different results. The results for the one-factor model, examined without modification, displayed a poor fit. Only the NNFI (0.90) and CFI (0.91) were within the acceptable ranges. However, the three-factor solution suggested a good-fitting model with NNFI and CFI of perfect indices as noted before. These findings suggest that 32 items in the scale represent three separate constructs rather than one, which is a good sign of discriminant validity according to Hair et al. (2014).

\section{DISCUSSION and CONCLUSION}

An attempt was made in the present study to develop and cross-validate a measurement scale as regards the student perception of a safe learning environment in the Turkish context by employing both PCA and PAF to compare results, but the priority was given to PCA as a conservative approach. Then, a CFA was run within a correlated traits model. Before performing the main analyses, the newly generated items $(N=85)$ underwent two rounds of expert review in terms of their relevance to the content domain and their comprehensibility to the target group. Item elimination or revision was carried out based on the CVI and modified kappa statistics at the initial stages of the study. These statistics yielded a strong content validity in terms of both the relevance and clarity of the remaining 59 items. The subsequent EFA, based on the data collected from 556 lower secondary students, suggested a scale with a nine-factor solution at the beginning. Nevertheless, three factors having at least $5 \%$ explained variances were preferred, as was also indicated by the inflexion point in the scree plot.

However, to prevent over-estimation in factor determination, Horn's parallel analysis was used, where the real eigenvalues were compared to those of randomly generated ones (Patil et al., 2008, Williams et al., 2010). As a result, a three-factor solution with 32 items was supported. These factors, extracted through PCA using Promax rotation, accounted for $50.622 \%$ of variances in total, which is considered adequate in the field of "humanities" (Williams et al., 2010, p. 6). However, PAF produced relatively smaller explained total variances of $45.546 \%$. The remaining unexplained variance, however, could be related to the other influencing factors that might affect student perception of a psychologically safe learning environment in the 
classroom setting. This, however, might need further investigation to reveal its other dimensions.

Besides, the factors were labeled as Teacher Approachability, Positive Peer Relationships, and the Lack of Identity Safety according to the existing literature (Boostrom, 1998; Beamon, 2001; Holley \& Steiner; 2005; Foldy et al., 2009). All the items under these factors had loadings of over 0.58 compared to the significant cutoff recommended (i.e. 0.45; Tabachnick and Fidell, $2013)$ and the item-total correlations were significant $(p<0.01)$. All of the items were in Likert type with five response categories, that is, $5=$ strongly agree, $4=$ agree, $3=$ undecided, $2=$ disagree, and $1=$ strongly disagree. Besides, all the items belonging to the third factor, Lack of Identity Safety, are negative either by meaning or by form. Therefore, they must be reversecoded in future use, as were done in this study before the analyses.

Furthermore, the first and second-order CFA validated the predicted construct of SLEPS by EFA. The factor loadings, $t$-test statistics, and goodness of fit indices indicated that the measurement model created, without modification, is within the acceptable standards to measure student perceptions as regards the safe learning climate in the classroom. All the factor loadings were $\geq 0.45$ with significant $t$ statistics $(p<0.001)$. Likewise, the Cronbach's alpha test of reliability after the EFA and CFA indicated that the variables in the sub-scales have an adequate level of internal consistency, although small differences were noticed in between. Besides, the total scores for the subscales can range from 16 to 80 for the first factor, 9 to 45 for the second, and 7-35 for the third. These scores could be interpreted or compared according to their arithmetic means. An increase in the mean of these scores may explain an increase in the students' perceived psychological safety in the classroom.

Furthermore, the convergent validity of the scale was supported according to the CR statistics. The comparison between the AVE statistics and the square of the correlation estimates between factors as well as the comparison between the fit indexes of one and three-factor models indicated good evidence for the discriminant validity. Simply put, the AVE for each construct was larger than its squared correlation and the 32 items in the scale support three construct model rather than one construct model. Taken together, in the wake of these results, this measurement model, the SLEPS (Safe Learning Environment Perception Scale), is a valid and reliable instrument to be used in future research.

Given that all the items in this measurement scale are in Turkish, only students who speak this language can respond it. In addition, the analyses were done based on the heterogeneous data from the lower secondary students (grade 5-8), studying at the public and private schools and the gifted center. This heterogeneity suggests the applicability of the scale in different contexts. The SLEPS, developed in the present study, could be utilized in collecting data from different schools or educational centers that accommodate students with diverse sociocultural and economic backgrounds. Although it was designed for the lower secondary students, its utility is assumed at the upper secondary level, too.

\section{ORCID}

Sayed Masood Haidari iD https://orcid.org/0000-0003-3221-6343

Fazilet Karakuş (iD https://orcid.org/0000-0002-6455-9845

\section{REFERENCES}

Aldrich, J. O. \& Cunningham, J. B. (2016). Using IBM ${ }^{\circledR}$ SPSS Statistics (2 $2^{\text {nd }}$ ed.). USA: SAGE Publications, Inc.

Beamon, G. W. (1993). Is Your Classroom "Safe" for Thinking? Introducing an Observation Instrument to Assess Classroom Climate and Teacher Questioning Strategies. Research in Middle Level Education, 17(1), 91-110. 
Beamon, G. W. (2001). M aking Classroom "Safe" for Adolescent Learning. Paper Presented at the $53^{\text {rd }}$ Annual Meeting of the American Association of Colleges for Teacher Education, Dallas, Texas.

Boostrom, R. (1998). 'Safe spaces': reflections on an educational metaphor. Curriculum Studies, 30(4), 397-408).

Brown, T. A. (2015). Confirmatory Factor Analysis for Applied Research (2nd ed). USA: The Guilford Press.

Capern, T. \& Hammond, L. (2014). Establishing Positive Relationships with Secondary Gifted Students and Students with Emotional/Behavioural Disorders: Giving These Diverse Learners What They Need. Australian Journal of Teacher Education, 39, 46-67. doi:10.14221/ajte.2014v39n4.5

Çokluk, Ö. \& Koçak, D. (2016) Using Horn's Parallel Analysis Method in Exploratory Factor Analysis for Determining the Number of Factors. Educational Sciences: Theory and Practice, 16, 537-551. doi:10.12738/estp.2016.2.0328

Field, A. (2009). Discovering Statistics Using SPSS (3 ${ }^{\text {rd }}$ ed.). Oriental Press, Dubai: SAGE Publication.

Foldy, E. R., Rivard, P. and Buckley, T. R. (2009). Power, Safety, and Learning in Racially Diverse Groups. Academy of Management Learning \& Education, 8(1), 25-41.

Frisby, B. N., Berger, E., Burchett, M., Herovic, E. \& Strawser, M. G. (2014). Participation Apprehensive Students: The Influence of Face Support and Instructor- Student Rapport on Classroom Participation. Communication Education, 63, 105 - 123. doi:10.1080/036 34523.2014.881516

Gayle, B. M., Cortez, D. \& Preiss, R. W. (2013). Safe Spaces, Difficult Dialogues, and Critical Thinking. International Journal for the Scholarship of Teaching and Learning, 7(2). doi:10.20429/ijsotl.2013.070205

Gillen, A., Wright, A. \& Spink, L. (2011). Student perceptions of a positive climate for learning: a case study. Educational Psychology in Practice, 27, 65 - 82. doi:10.1080/02667363.2 011.549355

Hair, J. F., Black, W. C., Babin, B. J., \& Anderson, R. E. (2014). Multivariate Data Analysis (7th ed.). USA: Pearson Education Limited.

Holley, L. C. \& Steiner, S. (2005) Safe Space: Student Perspectives on Classroom Environment, Journal of Social Work Education, 41(1), 49-64.

Hu, L. \& Bentler, P. M. (1999). Cutoff criteria for fit indexes in covariance structure analysis: Conventional criteria versus new alternatives. Structural Equation Modeling: A Multidisciplinary Journal, 6(1), 1-55. http://dx.doi.org/10.1080/10705519909540118

Kline, R. B. (2016). Principles and Practice of Structural Equation Modelling (4 ${ }^{\text {th }}$ ed). USA: The Guilford Press.

Lynn, M.R. (1986). Determination and Quantification of Content Validity. Nursing Research, 35, 382-385.

Patil, H. V., Singh, S. N., Mishra, S. \& Donavan, D. T. (2007). Parallel Analysis Engine to Aid in Determining Number of Factors to Retain [Computer software], Available from http://ires.ku.edu/ smishra/parallelengine.htm

Patil, H. V., Singh, S. N., Mishra, S. \& Donavan, D. T. (2008). Efficient theory development and factor retention criteria: Abandon the 'eigenvalue greater than one' criterion. Journal of Business Research, 61, 162-170. doi:10.1016/j.jbusres.2007.05.008

Pilot, D. F. and Beck, C. T. (2006). The Content Validity Index: Are You Sure You Know What's Being Reported? Critique and Recommendations. Research in Nursing and Health, 29, 489-497. doi:10.1002/nur.20147 
Pilot, D. F., Beck, C. T. and Owen, S. V. (2007). Focus on Research Methods: Is the CVI an Acceptable Indicator of Content Validity? Appraisal and Recommendations. Research in Nursing and Health, 30, 459-467. doi:10.1002/nur.20199

Pituch, K. A. \& Stevens, J. P. (2016). Applied Multivariate Statistics for the Social Science $6^{\text {th }}$ ed). New York: Routledge.

Raghallaigh, M. N. \& Cunniffe, R. (2013). Creating a safe climate for active learning and student engagement: an example from an introductory social work module. Teaching in Higher Education, 18, 93-105. doi:10.1080/13562517.2012.694103

Seçer, I. (2013). SPSS ve LISREL ile Pratik Veri Analizi: Analiz ve Raporlaştırma [Practical Data Analysis with SPSS and LISREL: Analysing and Reporting]. Ankara: Anı Yayıncilik.

Steven, J. P. (2009). Applied Multivariate Statistics for the Social Sciences (5 ${ }^{\text {th }}$ ed). USA: Routledge.

Tabachnick, B.G. \& Fidell, L. S. (2013). Using Multivariate Statistics ( $6^{\text {th }}$ Edition). USA: Pearson Education, Inc.

Turner, S. \& Braine, M. (2015). Unravelling the 'Safe' concept in teaching: what can we learn from teachers' understanding?. Pastoral Care in Education, 33(1), 47-62.

Walts, C. F., Strickland, O. L., \& Lenz, E. R. (2010). Measurement in Nursing and Health Research $\left(4^{\text {th }} \mathrm{ed}\right)$. New York: Springer Publishing Company, LLC.

Wanless, S. B. (2016). The Role of Psychological Safety in Human Development. Research in Human Development, 13, 6-14. doi:10.1080/15427609.2016.1141283

Williams, B., Onsman, A., and Brown, T. (2010). Exploratory factor analysis: A five-step guide for novices. Journal of Emergency Primary Health Care (JEPHC), 8(3), 1-13.

Zamanzadeh, V., Ghahramanian, A., Rassouli, M. Abbaszadeh, A. Alavi-Majid, H. and Nikanfar, A. R. (2015). Design and Implementation Content Validity Study: Development of an instrument for measuring Patient-Centered Communication. Journal of Caring Sciences, 4, 165-178. doi:10.15171/jcs.2015.017 


\section{APPENDIX}

\section{The SLEPS}

\section{Öğretmen Y aklaşımı (Teacher A pproachability)}

36) Sınıfta öğretmenlerime güvenirim. I trust my teachers in the class.

45) Sınıfımda öğretmenler hepimize eşit davranır. Teachers treat all of us equally in my class.

53) Sınıfımda öğretmenler ayrımcılık yapmaz. Teachers do not discriminate in my class.

6) Öğretmenlerimiz derslere aktif olarak katılmamız için çaba gösterir. Our teachers make every effort to encourage our active participation in the lessons.

30) Öğretmenlerim öğrenme eksikliklerimle ilgili sorunlarımı çözmeye çalışır. My teachers try to solve my problems in learning.

24) Öğretmenlerimiz bize iyi davranarak sınıfta güvende olduğumuzu hissettirir. Our teachers make us feel safe in the classroom by treating us well.

34) Öğretmenlerim arkadaşlarımızla olan sorunlarımızı çözmemize yardım eder. My teachers help us to solve our problems with our friends.

40) Öğretmenlerimiz kendimizi özgürce ifade edebileceğimiz ortamlar yaratır. Our teachers create environments where we can express ourselves freely.

58) Öğretmenlerim sınıfta eğlenceli bir şekilde ders anlatır. My teachers teach in an enjoyable way in the class.

48) Sınıfımdaki etkinliklerde herkese eşit katılım imkânı sağlanır. Everyone gets equal opportunities to participate in the activities in my class.

28) Derste verilen görevlerde-etkinliklerde hata yaptığımda öğretmenlerim kızmaz. My teachers do not get angry if I make mistake in the tasks given in the class.

59) Sınıfımda öğretmenler hepimize arkadaşça bir tavır sergiler. Teachers are friendly to all of us in the class.

18) Sınıfta öğretmenlerim beni sabırla dinler. My teachers listen to me patiently in the class.

47) Sınıfta öğretmenlerimle rahatlıkla iletişim kurarım. I can easily communicate with my teachers in the class.

21) Sınıfta öğretmenlerim beni başka öğrencilerle kıyaslamaz. My teachers do not compare me to other students in the class.

\section{Pozitif Akran İlşkileri (Positive Peer R elationships)}

19) Sınıfımda herkes birbirine iyi davranır. Everyone treats each other well in my class.

51) Sınıf arkadaşlarım beni önemser.

My classmates care about me. 
42) Sınıf arkadaşlarım yeni düşünceleri hoş karşılarlar.

My classmates welcome new ideas.

8) Sınıf arkadaşlarımla iyi anlaşırım.

I get along well with my classmates.

3) Sınıf arkadaşlarım düşüncelerime saygı duyar.

My classmates respect my ideas.

33) Sınıfımda fikir ayrılıkları kavgaya neden olmaz.

Disagreements in my class do not cause a fight.

41) Sınıfımda zıt düşünceler rahatlıkla paylaşılır.

Opposite ideas are easily shared in my class.

31) Sınıfta düşüncelerimi çekinmeden paylaşırım.

I share my thoughts without hesitation in the class.

22) Sınıfımda arkadaş ayrımı yapılmadan grup çalışmaları yürütülür.

The group works in my class are conducted without discrimination between friends.

\section{Kimliksel Güven Eksikliği (Lack of Identity Safety)}

55) Sınıfımda soru sorduğumda sınıf arkadaşlarımın dalga geçeceklerini düşünürüm. I think my classmates will make fun of me when I ask questions in my class.

39) Sinıfımda hakarete maruz kalmaktan korkarım.

I am afraid of being humiliated in my class.

50) Sınıf ortamında söz almaktan çekinirim.

I am afraid to speak in the class.

44) Sınıfımda fikirlerimin yanlış anlaşılmasından endişe ederim.

I fear that my ideas may cause misunderstooding in my class.

57) Sınıfımda konuşmak istediğimde bana söz hakkı verilmez.

I am not given the right to speak in my class when I want to.

32) Sınıfımda öğrenme sırasında yanlış yaptığımda dalga geçilmekten korkarım.

I am afraid of being made fun of when I make a mistake in my class.

46) Sınıfta çok soru sorduğumda arkadaşlarım olumsuz tepki gösterir.

My classmates show negative reactions when I ask many questions in the class. 